\title{
AKTIVITAS ANTIOKSIDAN EKSTRAK ETANOL HERBA PEGAGAN (Centella asiatica (L.) Urban) DENGAN METODE DPPH (2,2-Difenil-1-Pikrilhidrazil)
}

\author{
ANTIOXIDANT ACTIVITY ETHANOL EXTRACT OF GOTU KOLA (Centella asiatica (L.) \\ Urban) WITH DPPH METHOD (2,2-Diphenyl-1-Pikrilhidrazil)
}

Received: 23/08/2020; Revised: 04/11/2020; Accepted:28/11/2020; Published: 30/11/2020

Muhammad Ainul Yahya, lif Hanifah Nurrosyidah*

Program Studi DIII Farmasi, STIKES RS Anwar Medika, JI. Raya By Pass Krian KM 33, Sidoarjo

*Corresponding author: iifhanifanurrosyidah@gmail.com

\begin{abstract}
ABSTRAK
Pola hidup yang tidak sehat dan polusi udara menyebabkan jumlah radikal bebas dalam tubuh meningkat. Untuk melindungi tubuh dari radikal bebas terdapat senyawa antioksidan sebagai penangkal dan menstabilkan radikal bebas. Salah satu tumbuhan Indonesia yang bisa dimanfaatkan sebagai antioksidan adalah pegagan (Centella asiatica (L.) Urban. Penelitian ini bertujuan untuk mengetahui aktivitas antioksidan dari ekstrak etanol herba pegagan dengan metode DPPH (2,2-Difenil-1-pikrilhidrazi) yang dinyatakan dengan nilai $\mathrm{IC}_{50}$. Metode penelitian ini adalah pegagan (Centella asiatica (L.) Urban) diekstraksi dengan metode soxhletasi menggunakan pelarut etanol $96 \%$. Pengujian aktivitas antioksidan dilakukan dengan metode DPPH (2,2 Difenil-1-Pikrilhidrazil). Hasil pengujian aktivitas antioksidan pada ekstrak etanol herba pegagan menunjukkan nilai $\mathrm{IC}_{50}$ sebesar $78,20 \mathrm{ppm}$. Hal ini menunjukkan bahwa ekstrak etanol herba pegagan termasuk dalam kriteria antioksidan kuat.
\end{abstract}

Kata kunci: Antioksidan, DPPH, IC ${ }_{50}$, Pegagan (Centella asiatica (L.) Urban

\begin{abstract}
Unhealthy lifestyles and air pollution cause the number of free radicals in the body to increase. To protect the body from free radicals, there are antioxidant compounds as an antidote and stabilize free radicals. One of the Indonesian plants that can be used as antioxidants is gotu kola (Centella asiatica (L.) Urban. Objective: This study aims to determine the antioxidant activity of the ethanol extract of gotu kola herb using the DPPH (2,2-Diphenyl-1-pikrilhidrazil) method. with $I C_{50}$ value. Method: Gotu kola (Centella asiatica (L.) Urban) was extracted by the soxhletation method using $96 \%$ ethanol solvent. The testing of antioxidant activity was carried out using the DPPH (2.2 Diphenyl-1-Pikrihydrazil) method. Result: Test results of antioxidant activity The ethanol extract of gotu kola herb showed an $I C_{50}$ value of $78.20 \mathrm{ppm}$. Conclusion: This indicated that the ethanol extract of gotu kola herb was included in the criteria for strong antioxidants.
\end{abstract}

Keywords: Antioxidant, DPPH, $I C_{50}$, Gotu Kola (Centella asiatica (L.) Urban

How to cite: Yahya MA, Nurrosyidah IH. 2020. Antioxidant Activity Ethanol Extract of Gotu Kola (Centella asiatica (L.) Urban) with DPPH Method (2,2-Diphenyl-1-Pikrilhidrazil). Journal of Halal Product and Research. 3(2), 106-112, https://dx.doi.org/ 10.20473/jhpr.vol.3-issue.2.106-112. 


\section{PENDAHULUAN}

Pola hidup yang tidak sehat dan polusi udara dapat menyebabkan jumlah radikal bebas di dalam tubuh meningkat (Dominica and Handayani, 2019). Untuk melindungi tubuh dari radikal bebas, terdapat suatu senyawa antioksidan yang dapat menangkal dan menstabilkan radikal bebas (Julfitriyani et al., 2016).

Antioksidan adalah suatu senyawa yang dapat melindungi sel dari kerusakan yang disebabkan radikal bebas. Antioksidan akan berinteraksi dengan cara menstabilkan radikal bebas sehingga dapat mencegah kerusakan karena radikal bebas yang mungkin dapat terjadi (Hamid et al., 2010). Salah satu tumbuhan Indonesia yang bisa dimanfaatkan untuk tujuan tersebut adalah herba pegagan (Centella asiatica (L.) Urban). Herba Pegagan merupakan tanaman liar yang banyak tumbuh di berbagai tempat seperti di ladang, perkebunan maupun di pekarangan (Yusran et al. 2016). Herba Pegagan memiliki kandungan senyawa seperti polifenol, $\beta$ karoten, tanin, vitamin $C$ dan saponin seperti Madecassida dan Asiaticosida. Asiaticosida yang terdapat pada pegagan berfungsi sebagai antioksidan yang dapat menangkap radikal bebas, merevitalisasi pembuluh darah dan memperbaiki daya ingat (Anggraini et al. 2014).

Aktivitas antioksidan daun pegagan yang telah diteliti dalam penelitian sebelumnya menggunakan metode maserasi dengan pelarut metanol menunjukkan bahwa daun pegagan memiliki nilai IC50 sebesar 481,64 ppm (Wientarsih et al., 2013). Salah satu metode uji aktivitas antioksidan yang sering digunakan adalah metode DPPH (2,2-Diphenyl-1-Picrylhydrazyl). Mekanisme kerja dari metode DPPH adalah mereaksikan antioksidan yang terdapat pada sampel dengan DPPH dimana antioksidan akan mendonorkan atom hidrogennya sehingga akan menghambat aktivitas dari radikal bebas (Sitorus dkk., 2013). Oleh karena itu dilakukan penelitian ini dengan tujuan untuk menguji aktivitas antioksidan ekstrak etanol herba pegagan (Centella asiatica (L.) Urban) dengan metode DPPH (2,2-Diphenyl-1Picrylhydrazyl) yang dinyatakan dengan nilai $\mathrm{IC}_{50}$.

\section{METODE PENELITIAN}

\section{Bahan dan Alat}

Bahan yang digunakan yaitu simplisia pegagan, vitamin C, metanol p.a, DPPH (2,2-Diphenyl-1Picrylhydrazy), etanol 96\%, aquadest, kloroform, $\mathrm{HCl}$ 0,5 N, pereaksi Mayer, Bauchardat, amonia 25\%, $\mathrm{FeCl}_{3}$. Adapun alat yang digunakan yaitu satu set alat ekstraksi soxhlet, rotary evaporator, spektrofotometer UV-Vis, timbangan analitik, kuvet, serta berbagai alat gelas yang biasa digunakan di Laboratorium..

\section{Metode \\ Pembuatan Ekstrak Etanol Herba Pegagan}

Ekstraksi dilakukan dengan metode soxhletasi. Serbuk pegagan sebanyak 400 gram dibagi menjadi 4 bagian sama banyak, proses sokletasi dilakukan sebanyak 4 kali. Serbuk pegagan diekstraksi dengan etanol $96 \%$ menggunakan alat soxhlet pada suhu $60-80^{\circ} \mathrm{C}$. Kemudian ditunggu hingga zat aktif dalam simplisia tersari seluruhnya yang ditandai dengan jernihnya cairan yang lewat tabung sifon. Cairan yang diperoleh dari 4 kali sokletasi selanjutnya diuapkan dengan rotary evaporator pada suhu $60^{\circ} \mathrm{C}$ sampai diperoleh ekstrak kental (Nurrosyidah et al. 2019).

\section{Skrining Fitokimia}

1. Identifikasi Sterol dan Triterpenoid. Sebanyak 0,5 gram ekstrak kental dilarutkan dalam kloroform, kemudian disaring dan filtrat diuji dengan uji Salkowski yaitu filtrat ditambahkan beberapa tetes asam sulfat pekat dan diamati perubahan warna yang terjadi. Warna merah di lapisan bawah positif sterol dan warna kuning keemasan menunjukkan adanya triterpenoid (Abdillah et al., 2017).

2. Identifikasi Alkaloid. Ekstrak kental dimasukkan ke dalam masing-masing tabung reaksi kemudian ditetesi: (a) $\mathrm{HCl}$ 0,5 N dan pereaksi Mayer, jika mengandung alkaloid maka akan menghasilkan endapan kuning. (b) $\mathrm{HCl} 0,5 \mathrm{~N}$ dan pereaksi Bauchardat, jika mengandung alkaloid maka akan menghasilkan endapan coklat (Syarif et al. 2015).

Journal of Halal Product and Research (JHPR)

e-ISSN: 2654-9778; p-ISSN: 2654-9409 
3. Identifikasi Flavonoid. Ekstrak kental ditambahkan amonia 25\%. Jika mengandung flavonoid akan berwarna kuning kehijauan (Nurrosyidah et al., 2019).

4. Identifikasi Saponin. Sebanyak 0,5 gram ekstrak dilarutkan dalam $5 \mathrm{ml}$ air suling lalu dikocok dan diamati terbentuknya buih stabil (Abdillah dkk., 2017).

5. Identifikasi tanin. Ekstrak kental ditambahkan beberapa tetes $\mathrm{FeC}_{\mid 3}$, jika mengandung tanin akan berwarna hijau, biru sampai hitam (Nurrosyidah et al. 2019).

\section{Pengujian Aktivitas Antioksidan Dengan Metode DPPH (2,2-Diphenyl-1-Picrylhydrazyl)}

1. Pembuatan Larutan DPPH. Pembuatan larutan DPPH 100 ppm dibuat dengan cara menimbang DPPH sebanyak $5 \mathrm{mg}$ kemudian ditambahkan metanol p.a hingga $50 \mathrm{~mL}$.

2. Penentuan Panjang Gelombang Serapan Maksimum DPPH. $1 \mathrm{~mL}$ larutan DPPH $100 \mathrm{ppm}$ dimasukkan ke dalam tabung reaksi, selanjutnya ditambahkan $3 \mathrm{ml}$ metanol p.a dan dihomogenkan. Diinkubasi pada suhu ruang selama 30 menit. Selanjutnya ditentukan panjang gelombang optimumnya, diukur absorbansinya pada panjang gelombang $510-525 \mathrm{~nm}$ (Syaifuddin, 2015).

3. Pembuatan Larutan Sampel Ekstrak Pegagan. Ditimbang ekstrak pegagan sebanyak $25 \mathrm{mg}$, kemudian dilarutkan dalam $25 \mathrm{~mL}$ metanol p.a, dimasukkan dalam labu ukur sehingga diperoleh larutan induk 1000 ppm. Dari larutan induk dibuat seri konsentrasi menjadi 4, 8, 12, 16, 20 dan 100 ppm.

4. Pembuatan Larutan Vitamin $\mathrm{C}$ sebagai Pembanding. Ditimbang Vitamin $\mathrm{C}$ sebanyak $5 \mathrm{mg}$. Dilarutkan dengan metanol p.a secukupnya, dimasukkan ke dalam labu ukur $50 \mathrm{ml}$ lalu ditambahkan metanol p.a hingga $50 \mathrm{ml}$, sehingga diperoleh konsentrasi sebesar $100 \mathrm{ppm}$. Dari larutan induk dibuat seri konsentrasi menjadi 2, 4, 6, 8 dan 10 ppm.

5. Pengukuran Serapan dengan spektrofotometer UV-Vis. Masing-masing larutan sampel dan larutan pembanding, dipipet $1 \mathrm{~mL}$, dimasukkan ke dalam tabung reaksi, ditambahkan $1 \mathrm{~mL}$ DPPH 100 ppm dan ditambahkan $2 \mathrm{~mL}$ metanol p.a, dikocok hingga homogen. Larutan ini diinkubasi pada suhu ruang selama 30 menit dan diukur serapannya pada panjang gelombang optimum DPPH yang diperoleh. Dilakukan replikasi sebanyak 3 kali.

6. Penentuan \% Inhibisi dan Nilai $\mathrm{IC}_{50}$

$\%$ Inhibisi $=$ Abs blanko - Abs sampel $\times 100 \%$

\section{Abs Blanko}

Nilai $I_{50}$ dihitung menggunakan persamaan regresi linier dari $y=b x+a$ antara konsentrasi larutan uji (x) dengan \% Inhibisi (y).

\section{HASIL DAN PEMBAHASAN}

\section{Ekstraksi Pegagan}

Proses pembuatan ekstrak pegagan dilakukan dengan menggunakan metode soxhletasi. Metode ini dipilih karena memiliki keuntungan diantaranya jumlah pelarut yang digunakan lebih sedikit serta komponen yang diekstraksi dapat tersaring sempurna karena dilakukan sirkulasi berkali-kali (Putri, 2018). Sedangkan untuk pelarut yang digunakan adalah etanol $96 \%$. Pemilihan pelarut etanol $96 \%$ tersebut didasarkan pada kemudahannya saat diuapkan serta sifatnya yang mampu melarutkan hampir semua zat, baik yang bersifat polar, semi polar dan nonpolar (Sulastri dkk., 2015). Adapun hasil yang diperoleh dari ekstraksi pegagan dapat dilihat pada Tabel 1 berikut.

Tabel 1. Hasil Ekstraksi Pegagan

\begin{tabular}{cccc}
\hline Sampel & Bobot simplisia & Bobot Ekstrak & Rendemen \\
\hline Pegagan & $400 \mathrm{gram}$ & $50 \mathrm{gram}$ & $12,5 \%$ \\
\hline
\end{tabular}

Journal of Halal Product and Research (JHPR)

e-ISSN: 2654-9778; p-ISSN: 2654-9409 


\section{Skrining Fitokimia}

Ekstrak pegagan yang sudah diperoleh selanjutnya dilakukan pengujian fitokimia untuk mengetahui kandungan metabolit sekunder yang terkandung didalam ekstrak pegagan. Pengujian fitokimia yang dilakukan meliputi sterol, triterpenoid, alkaloid, flavonoid saponin dan lain lain. Hasil pengujian fitokimia dapat dilihat pada Tabel 2 berikut.

Tabel 2. Skrining Fitokimia Ekstrak Pegagan

\begin{tabular}{llcl}
\hline No & Metabolit Sekunder & Hasil & Keterangan \\
\hline 1 & Triterpenoid & - & Tidak terbentuk warna kuning keemasan \\
\hline 2 & Sterol & + & Terbentuk warna merah \\
\hline 3 & Alkaloid & + & $\begin{array}{l}\text { Terbentuk endapan kuning (Mayer) } \\
\text { Terbentuk endapan coklat (Et al.,) }\end{array}$ \\
& & & Terbentuk warna kuning kehijauan \\
\hline 4 & Flavonoid & + & Terbentuk busa yang stabil \\
\hline 5 & Saponin & + & Terbentuk warna biru kehitaman \\
\hline
\end{tabular}

Keterangan: $\quad(+)=$ mengandung senyawa yang diuji

$(-)=$ tidak mengandung senyawa yang diuji

Dari tabel tersebut dapat diketahui ekstrak etanol herba pegagan positif mengandung senyawa sterol, alkaloid, flavonoid, saponin dan lain lain. Sedangkan pada pengujian triterpenoid diperoleh hasil yang negatif karena sampel tidak mengalami perubahan warna yang sesuai dengan indikator.

\section{Uji Aktivitas Antioksidan Metode DPPH}

Pengujian aktivitas antioksidan dilakukan dengan menggunakan metode DPPH. Pemilihan metode ini karena merupakan metode yang sederhana, mudah, cepat dan serta hanya memerlukan sedikit sampel untuk evaluasi aktivitas antioksidan. Larutan radikal bebas DPPH memiliki atom nitrogen yang tidak berpasangan. Reaksi DPPH dengan atom hidrogen yang terdapat dalam antioksidan dapat membuat larutan DPPH menjadi berkurang reaktivitasnya yang ditunjukkan dengan memudarnya warna ungu menjadi kuning (Amanda et al. 2019). Sebagai pembanding pada penelitian ini digunakan vitamin C. Alasan penggunaan vitamin $\mathrm{C}$ sebagai pembanding, karena vitamin $\mathrm{C}$ merupakan antioksidan sekunder yang dapat menangkap radikal bebas, mencegah terjadinya reaksi berantai dan aktivitas antioksidannya tinggi. Vitamin $\mathrm{C}$ mempunyai gugus hidroksil yang bertindak sebagai penangkap radikal bebas (Isnindar et al. 2011).

Pengujian aktivitas antioksidan dilakukan dengan membuat larutan DPPH yang selanjutnya dilakukan penentuan panjang gelombang maksimumnya. Proses penentuan panjang gelombang maksimum ini bertujuan untuk mendapatkan panjang gelombang yang memiliki absorbansi maksimal. Penentuan panjang gelombang ini dilakukan pada rentang 510-525 nm Hasil penentuan panjang gelombang maksimum DPPH yang didapat adalah $515 \mathrm{~nm}$. Setelah diperoleh panjang gelombang maksimum, tahap selanjutnya yaitu pengukuran absorbansi sampel setiap konsentrasi serta perhitungan $\%$ inhibisi. Hasil pengukuran absorbansi dan \% inhibisi yang diperoleh dapat dilihat Table 3 dan Tabel 4 berikut 
Tabel 3. Hasil Absorbansi dan \% Inhibisi Ekstrak Etanol Herba Pegagan.

\begin{tabular}{|c|c|c|c|c|}
\hline Sampel & $\begin{array}{c}\text { Konsentrasi } \\
\text { (ppm) }\end{array}$ & $\begin{array}{l}\text { Absorbansi } \\
\text { Blanko }\end{array}$ & $\begin{array}{c}\text { Absorbansi } \\
\text { Sampel* }\end{array}$ & $\begin{array}{c}\% \\
\text { Inhibisi* }\end{array}$ \\
\hline \multirow[t]{6}{*}{ Ekstrak Pegagan } & 4 & 0,711 & 0,628 & $11,67 \%$ \\
\hline & 8 & & 0,625 & $12,09 \%$ \\
\hline & 12 & & 0,619 & $12,93 \%$ \\
\hline & 16 & & 0,616 & $13,36 \%$ \\
\hline & 20 & & 0,610 & $14,20 \%$ \\
\hline & 100 & & 0,264 & $62,86 \%$ \\
\hline
\end{tabular}

Keterangan: * $=$ Pengukuran dilakukan sebanyak 3 kali

Tabel 4. Hasil Absorbansi dan \% Inhibisi Vitamin C.

\begin{tabular}{|c|c|c|c|c|}
\hline Sampel & $\begin{array}{l}\text { Konsentrasi } \\
(p p m)\end{array}$ & $\begin{array}{l}\text { Absorbansi } \\
\text { Blanko }\end{array}$ & $\begin{array}{c}\text { Absorbansi } \\
\text { Sampel }^{*}\end{array}$ & $\begin{array}{c}\% \\
\text { Inhibisi }^{\star}\end{array}$ \\
\hline \multirow[t]{5}{*}{ Ekstrak Pegagan } & 2 & 0,711 & 0,655 & $7,87 \%$ \\
\hline & 4 & & 0,603 & $15,18 \%$ \\
\hline & 6 & & 0,570 & $19,83 \%$ \\
\hline & 8 & & 0,550 & $22,64 \%$ \\
\hline & 10 & & 0,491 & $30,94 \%$ \\
\hline
\end{tabular}

Keterangan: * $=$ Pengukuran dilakukan sebanyak 3 kali

Berdasarkan tabel 3 dan 4 dapat diketahui semakin besar konsentrasi larutan sampel maka semakin kecil nilai absorbansi yang diperoleh. Semakin kecil nilai absorbansi maka akan semakin besar nilai \% inhibisi. Hal ini dikarenakan semakin tinggi konsentrasi larutan maka aktivitas antioksidannya semakin tinggi. Setelah mendapatkan data \% inhibisi selanjutnya dibuat persamaan regresi linier antara konsentrasi larutan $(\mathrm{x})$ dan \% inhibisi $(\mathrm{y})$. Hasil persamaan regresi larutan sampel dapat dilihat pada gambar 1 dan gambar 2 berikut.

Gambar 1. Persamaan Regresi Linier Ekstrak Etanol Herba Pegagan

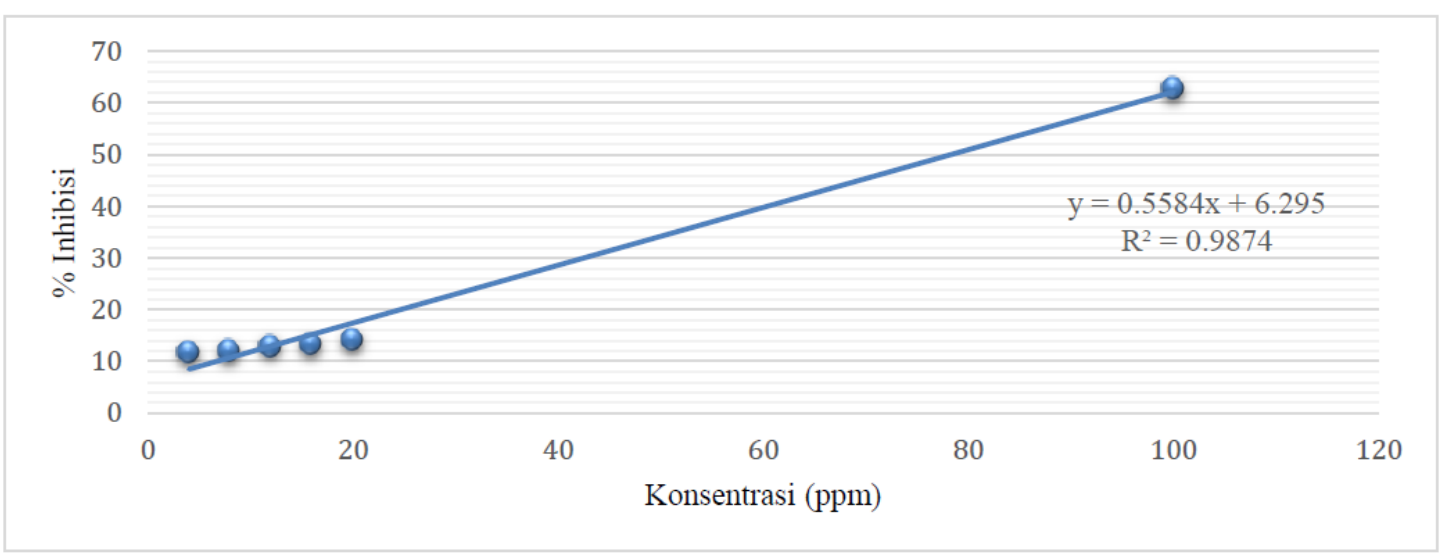

Journal of Halal Product and Research (JHPR)

e-ISSN: 2654-9778; p-ISSN: 2654-9409 


\section{Gambar 2. Persamaan Regresi Linier Vitamin C}

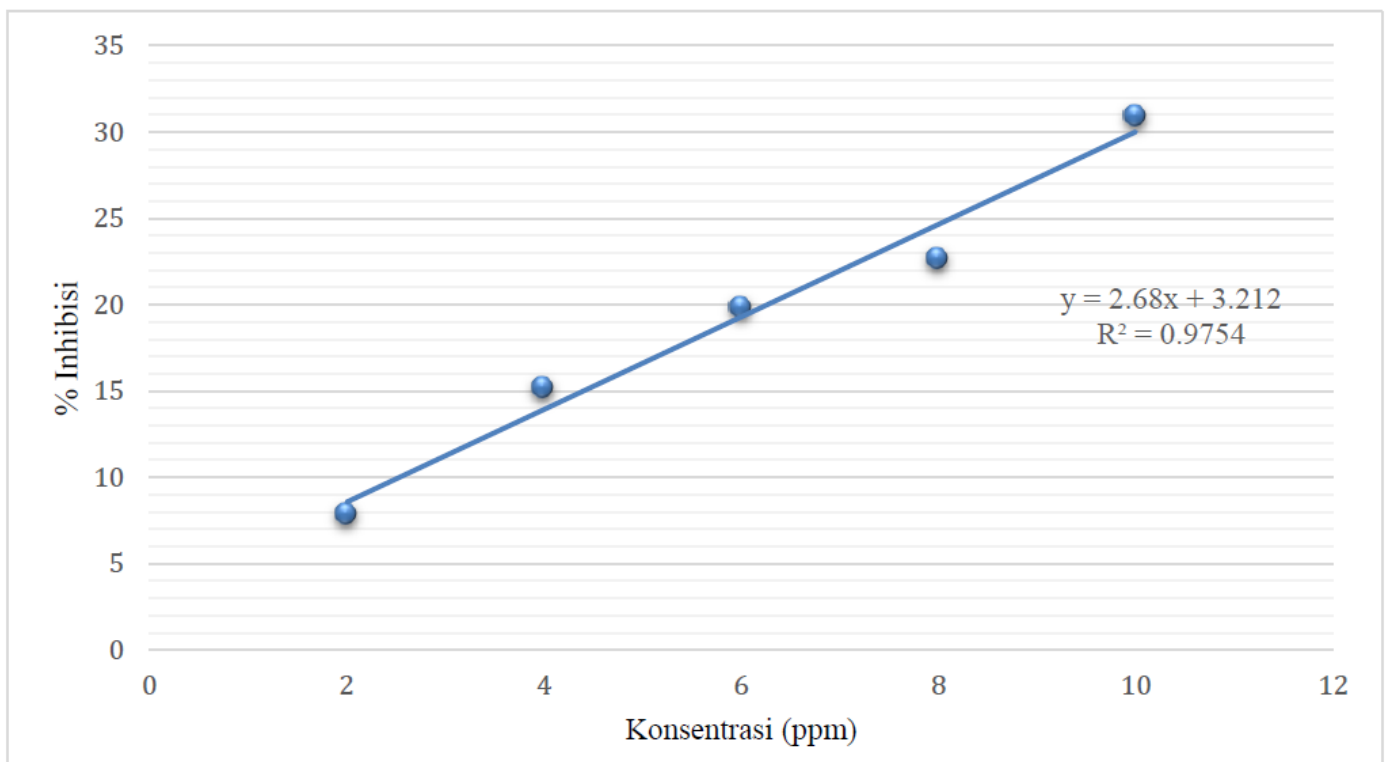

Persamaan regresi linier yang sudah didapat selanjutnya dilakukan perhitungan nilai $I C_{50}$. Nilai $I C_{50}$ merupakan konsentrasi senyawa antioksidan yang dibutuhkan untuk menangkap radikal bebas DPPH sebanyak $50 \%$. Semakin kecil nilai $\mathrm{IC}_{50}$ maka semakin besar aktivitas antioksidannya. Hasil perhitungan nilai $I_{50}$ dapat dilihat pada Tabel 5.

Tabel 5. Nilai IC $\mathrm{C}_{50}$ Ekstrak Etanol Herba Pegagan dan Vitamin C

\begin{tabular}{lc}
\multicolumn{1}{c}{ Sampel } & Nilai IC $\mathbf{C}_{50}$ \\
\hline Ekstrak Pegagan & $78,26 \mathrm{ppm}$ \\
\hline Vitamin C & $17,45 \mathrm{ppm}$ \\
\hline
\end{tabular}

Menurut Andriani et al. (2015) dalam Syafrinal dan Sari Ramadhani (2019) aktivitas antioksidan suatu senyawa dapat digolongkan menjadi antioksidan sangat kuat jika nilai $\mathrm{IC}_{50}$ kurang dari 50 ppm, dikatakan kuat jika nilai $\mathrm{IC}_{50}$ 50-100 ppm, dikatakan sedang jika nilai $\mathrm{IC}_{50}$ 100-150 ppm, dikatakan lemah jika nilai $I_{50} 150-200$ ppm dan sangat lemah jika nilai $I_{50}$ lebih dari 200 ppm. Berdasarkan kriteria tersebut ekstrak pegagan termasuk dalam kriteria antioksidan kuat dan vitamin $\mathrm{C}$ termasuk dalam kriteria antioksidan sangat kuat.

Berdasarkan hasil uji aktivitas antioksidan dapat diketahui bahwa aktivitas antioksidan ekstrak pegagan lebih rendah jika dibandingkan dengan vitamin C. Rendahnya aktivitas antioksidan tersebut diduga disebabkan oleh berbagai faktor, diantaranya karena metode ekstraksi yang digunakan diduga tidak cukup menarik komponen kimia yang bersifat antioksidan dalam pegagan. Selain itu diduga karena vitamin C merupakan zat atau senyawa tunggal yang memiliki aktivitas antioksidan sangat kuat sedangkan pada ekstrak senyawa masih dalam bentuk kompleks atau masih gabungan antara komponen-komponen senyawa lain.

\section{KESIMPULAN}

Berdasarkan penelitian yang dilakukan dapat disimpulkan bahwa ekstrak etanol herba pegagan memiliki aktivitas antioksidan dengan nilai $\mathrm{IC}_{50}$ sebesar $78,26 \mathrm{ppm}$ yang tergolong dalam antioksidan kuat. 


\section{DAFTAR PUSTAKA}

Abdillah M, Khoirotun Nazilah NR, Eva A. 2017. Identification of Active Subtance in Ajwa Date (Phoenix dactylvera L.) Fruit Flesh Methanol Extract. BIOTROPIC The Journal of Tropical Biology. Vol 1(01): Hal 32-39.

Amanda TTM, Defny SW, Adithya Y. 2019. Uji Aktivitas Antioksidan Ekstrak Etanol Kulit Batang Mahnoni (Swietenia mahagoni Jacq.) Menggunkan Metode DPPH (1,1-diphenyl-2-picrylhydrazyl). PHARMACON-Jurnal Ilmiah Farmasi. Vol 8(3): Hal 132-139.

Andriani YNM, Ramli, Syamsumir DF, Kassim MNI, Jaafar J, Aziz NA, Marlina L, Musa NS, Mohamad H. 2015. Phytochemical Analysis, Antioxidant, Anti bacterial and Cytotoxicity Properties of Keys and Cores Parts of Pandanus tectorius Fruits. Arabian Journal of Chemistry.

Anggraini T, Diana S, Sahadi DI, Firdaus A. 2014. Pengaruh Penambahan Peppermint (Mentha piperita, L.) Terhadap Kualitas Teh Daun Pegagan (Centella asiatica, L. Urban). Jurnal Litbang Industri, Vol 4(2): Hal 79-88.

Dominica D, Handayani D. 2019. Formulasi dan Evaluasi Sediaan Lotion dari Ekstrak Daun Lengkeng (Dimocarpus longan) sebagai Antioksidan. Jurnal Farmasi dan IImu Kefarmasian Indonesia. Vol 6(1): Hal 1-7.

Hamid AA, Aiyelaagbae OO, Usman LA, Ameen OM, Lawal A. 2010. Antioxidant: Its Medicinal and Pharmacological Applications. Vol 4(8). Pp 142-151.

Julfitriyani, Runtuwene RM, Wewengkang D. Uji Aktivitas Antioksidan Dan Toksisitas Ekstrak Etanol Daun Foki Sabarati (Solanum torvum). PHARMACON. Vol. 5(3): Hal 94-101.

Isnindar, Wahyuono S, Setyowati EP. 2011. Isolasi dan Identifikasi Senyawa Antioksidan Daun Kesemek (Diospyros kaki Thunb) Dengan Metode DPPH (2,2-difenil-1 pikrilhidrazil). Majalah Obat Tradisional. Vol. 16(3): Hal 157-164.

Nurrosyidah IH, Retna H, Milu A. 2019. Uji Aktivitas Antibakteri Sediaan Gel Ekstrak Etanol Pegagan (Centela asiatica L.) Terhadap Bakteri Staphylococcus aureus Secara In Vitro. Jurnal of Pharmaceutical Care Anwar Medika. Vol. 2(1): Hal 1-10.

Putri IM. 2018. Penetapan Kadar Lemak Pada Produk Yoghurt Nabati Dengan Metode Ekstraksi Soxhlet. Karya Tulis IImiah. Fakultas IImu Kesehatan. Surakarta.

Sitorus E, Momuat LI, Katja DG. 2013. Aktivitas Antioksidan Tumbuhan Suruhan (Peperomia pellucida [L.] Kunth). Jurnal IImiah Sains, 13(1), pp.80-85.

Sulastri E, Oktaviani C, Yusriadi. 2015. Formulasi Mikroemulsi Ekstrak Bawang Hutan dan Uji Aktivitas Antioksidan. Jurnal Pharmascience, 2(2), pp, 1-14.

Syafrinal, Ramadhani S. 2019. Uji Aktivitas Antioksidan Ekstrak Kulit Batang Dalu-Dalu (Salix tetrasperma Roxb) Menggunakan Metode DPPH (1,1 - Difenil - 2 pikrilhidrazil). Jurnal Teknologi Pertanian. Vol. 8(1): Hal 1-7.

Syaifuddin. 2015. Uji Aktivitas Antioksidan Bayam Merah (Alternanthera amoena Voss.) Segar dan Rebus Dengan Metode DPPH. Skripsi. Fakultas IImu Tarbiyah dan Keguruan UIN Walisongo. Semarang.

Syarif S, Rachmat K, Nurul I. 2015. Uji Aktivitas Antioksidan Terong Belanda (Solanum betaceum Cav.) Dengan Metode FRAP. As-Syifaa. Vol. 7(1): Hal 26-33.

Wientarsih, Sulistyantie IHRS, Irma MH. 2013. Aktivitas Antioksidan Fraksi Metanol Daun Pegagan (Centella asiatica (L.) Urban). Fitofarmaka. Vol (3)2: Hal 1-8.

Yusran, Asriani I, Asri S. 2016. Bioaktiviras Ekstrak Metanol Daun Pegagan (Centella asiatica L.) Terhadap Pertumbuhan Bakteri Mycobacterium tuberculosis. Al-Kimia. 